\title{
Article \\ Financing Efficiency Evaluation and Influencing Factors of Hydrogen Energy Listed Enterprises in China
}

\author{
Yuanying Chi ${ }^{1}$, Meng Xiao ${ }^{1}$, Yuexia Pang ${ }^{1, *}$, Menghan Yang ${ }^{1}$ and Yuhao Zheng ${ }^{2}$ \\ 1 School of Economics and Management, Beijing University of Technology, Beijng 100124, China; \\ goodcyy@bjut.edu.cn (Y.C.); emmahsiao@emails.bjut.edu.cn (M.X.); yangmenghan117@sina.com (M.Y.) \\ 2 Norwich Business School, University of East Anglia, Norwich NR4 7TJ, UK; cnf18fra@uea.ac.uk \\ * Correspondence: pangyuexia@bjut.edu.cn
}

check for updates

Citation: Chi, Y.; Xiao, M.; Pang, Y.; Yang, M.; Zheng, Y. Financing Efficiency Evaluation and Influencing Factors of Hydrogen Energy Listed Enterprises in China. Energies 2022, 15, 281. https://doi.org/10.3390/ en15010281

Academic Editor: Luigi Aldieri

Received: 8 December 2021

Accepted: 22 December 2021

Published: 1 January 2022

Publisher's Note: MDPI stays neutral with regard to jurisdictional claims in published maps and institutional affiliations.

Copyright: (C) 2022 by the authors. Licensee MDPI, Basel, Switzerland. This article is an open access article distributed under the terms and conditions of the Creative Commons Attribution (CC BY) license (https:// creativecommons.org/licenses/by/ $4.0 /)$.

\begin{abstract}
Existing studies of financing efficiency concentrate on capital structure and a single external environment or internal management characteristic. Few of the studies include the internal and external financing environments at the same time for hydrogen energy industry financing efficiency. This paper used the data envelopment analysis (DEA) model and the Malmquist index to measure the financing efficiency of 70 hydrogen energy listed enterprises in China from 2014 to 2020 from both static and dynamic perspectives. Then, a tobit model was constructed to explore the influence of external environment and internal factors on the financing efficiency. The contributions of this paper are studying the internal and external financing environments, and integrating financing cost efficiency and capital allocation efficiency into the financing efficiency of hydrogen energy enterprises. The results show that, firstly, the financing efficiency of China's hydrogen energy listed enterprises showed an upward trend during the years 2014-2020. Secondly, China's hydrogen energy enterprises mainly gather in the eastern coastal areas, and their financing efficiency is more than that in western areas. Thirdly, the regional economic development level, enterprise scale, financing structure, capital utilization efficiency and profitability have significant effects on the financing efficiency. These results can promote the achievement of "carbon neutrality" in China.
\end{abstract}

Keywords: hydrogen energy; financing efficiency; DEA model; Malmquist index; tobit model

\section{Introduction}

The carbon peak and carbon neutrality goals set high requirements for China's economic development and ecological civilization construction, and it has become a consensus to promote the economy's development to a green and low-carbon model [1]. Improving the clean and efficient utilization of fossil energy and vigorously developing clean energy are of strategic importance for China to achieve the vision of "carbon neutrality" [2]. In this context, hydrogen energy, as a clean and efficient secondary energy source, can promote the clean and efficient utilization of traditional fossil energy and support the large-scale renewable energy development [3]. Therefore, the hydrogen energy industry has become a focus. Recently, China's hydrogen energy industry has seen a spurt of entrepreneurial projects, and many enterprises are actively laying out the hydrogen energy industry chain. The hydrogen energy industry has ushered in an unprecedented golden development period [4]. Since 2020, with the promulgation of "Reward Instead of Subsidy" for fuel cell vehicles, the planning and layout of China's hydrogen energy industry have gradually accelerated. The financing speed has been significantly accelerated, and the financing fever has also continued to rise [5].

Capital is necessary for the production and operation activities of enterprises. As an important economic act to obtain capital, financing has a long-term and profound significance for enterprises' high-quality development [6]. The Modigliani-Miller theorem (MM theorem) is considered as the theoretical cornerstone of enterprise financing. In 1959, 
Modigliani and Miller proposed that in the frictionless capital market, the market value of enterprises has nothing to do with their capital structure [7]. In 1963, they perfected MM theory and believed that the increase in liabilities could increase the value of enterprises when corporate income tax was considered. As the interest of liabilities is tax-free expenditure, it can reduce the comprehensive capital cost of enterprises [8].

On this basis, scholars have carried out multi-level research on the internal relationship between capital structure and enterprise value. Romano et al. pointed out that factors such as enterprise scale, business plan and business objectives have a significant impact on enterprise debt financing, which will further affect enterprise financing decision making and financing efficiency [9]. Almeida and Wolfenzon believe that the increasing demand for external financing will encourage the flow of capital to projects with high production efficiency, to improve the financing efficiency of enterprises [10]. Additionally, some scholars have pointed out that the financing efficiency and its influencing factors of enterprises will also vary according to the nature of enterprises and industries. For example, science and technology enterprises prefer equity financing [11]. From the above literature, it can be seen that the existing foreign research is still limited to the perspective of capital structure, which may have a great relationship with the existing property organization system or property right system in the West. Due to the decentralization, socialization and marketization of property organizations in Western countries, the private characteristics of the property right system and the relatively perfect capital market, enterprise financing naturally has an internal meaning of efficiency [12].

Although the domestic capital market started later, it is growing rapidly, with the continuous promotion of market-oriented reform and the continuous improvement in the regulatory system [13]. The research on enterprise financing is also deepening, and the two-way interaction between enterprise financing and enterprise organizational efficiency is further included in the research category [12]. The early research mainly focused on scientific and innovative small and medium-sized enterprises [14]. Recently, more attention has been paid to new energy enterprises, due to climate change and environmental pollution caused by traditional energy [15]. China's new energy industry is developing rapidly and has begun to take shape. However, as a capital- and technology-intensive industry, the new energy industry needs to invest a significant amount of capital and time cost in technology at the initial stage of development. Therefore, new energy enterprises generally face severe financing problems [16]. Due to the high investment and maintenance costs, complex construction issues and economic returns that are not always high in renewable energy projects, obtaining initial capital can be very difficult for these renewable energy enterprises. Therefore, the investment of these enterprises is often supported by public and public-private partnership capital [17,18].

From the above literature, existing studies concentrate on financing status and characteristics of new energy enterprises [19], financing preferences of different enterprises [16], financing influencing factors [20-22] and new financing models on the basis of debt financing and equity financing [23]. Although existing scholars have explored the new energy industry, there is no special research on the financing efficiency of hydrogen energy enterprises. Meanwhile, most studies focus on the capital structure when discussing the financing efficiency, and on a single external environment or internal management characteristic when exploring the influencing factors of financing efficiency. Few scholars consider the internal and external financing environments at the same time or combine the financing cost efficiency and capital allocation efficiency to conduct an empirical study. At present, China's hydrogen energy industry is still in the early stage of development. Improving the financing efficiency of hydrogen energy enterprises is of great significance to realize the high-quality development of hydrogen energy enterprises. Additionally, it will also help China quickly reach the strategic goal of clean energy transformation and realize the high-quality sustainable development of the economy [24]. Therefore, this paper applied the DEA model and the Malmquist index to measure the financing efficiency of 70 hydrogen energy listed enterprises in China from 2014 to 2020 from both static and dynamic 
perspectives. To ensure the authenticity and stability of the regression results, various regression tests including correlation coefficient, multicollinearity and cointegration tests were employed in this study. Then, a tobit model was constructed to explore the internal and external drivers of the financing efficiency of hydrogen energy enterprises and put forward corresponding development suggestions. Due to the single research perspective, the existing literature has some limitations and cannot fully reflect the financing efficiency of hydrogen energy enterprises. The contribution of this study is the evaluation of financing efficiency and its influencing factors of hydrogen energy enterprises from multiple angles. This study considers the internal and external financing environments at the same time and combines the financing cost efficiency and capital allocation efficiency to conduct an empirical study, which are two features that have not been implemented in existing articles. The results in this paper may provide a basis for policy recommendations that promote the country's "dual carbon" goal of achieving its carbon emission peak by 2030 and carbon neutrality before 2060 .

\section{DEA Model for Hydrogen Energy Financing Efficiency Evaluation}

Understanding the concepts of financing efficiency, and the techniques available for its measurement, is of fundamental importance [25]. In this paper, the financing efficiency of hydrogen energy listed enterprises in China was studied from two perspectives: cost efficiency and capital allocation efficiency of corporate financing [26]. On the one hand, whether it is more efficient for enterprises to pay lower costs to obtain the required funds is studied. On the other hand, whether it is highly efficient for enterprises to use the raised funds to obtain greater benefits is studied [27]. Combining the characteristics of hydrogen energy listed enterprises in China and the availability of data, this paper selected the data of 70 listed enterprises in China from 2014 to 2020 and used three items as input indicators: total assets $\left(X_{1}\right)$, asset-liability ratio $\left(X_{2}\right)$ and financing cost ratio $\left(X_{3}\right)$; return on equity $\left(Y_{1}\right)$, operating income growth rate $\left(Y_{2}\right)$, total asset turnover ratio $\left(Y_{3}\right)$ and basic earnings per share $\left(Y_{4}\right)$ were taken as output indicators $[16,28]$. Table 1 shows the index selection results of DEA model.

Table 1. Index selection results of the DEA model.

\begin{tabular}{|c|c|c|c|}
\hline Indicator Type & Indicator Name & Variable & Variable Description \\
\hline \multirow{3}{*}{ Input Index } & total assets & $X_{1}$ & reflects the capital scale of the enterprise \\
\hline & asset-liability ratio & $X_{2}$ & $\begin{array}{c}\text { reflects the capital structure and financing risk of } \\
\text { the enterprise }\end{array}$ \\
\hline & financing cost rate & $X_{3}$ & reflects enterprise financing costs \\
\hline \multirow{4}{*}{ Output Index } & return on equity & $Y_{1}$ & reflects the profitability of the enterprise \\
\hline & operating income growth rate & $Y_{2}$ & reflects the growth ability of the enterprise \\
\hline & total asset turnover & $Y_{3}$ & $\begin{array}{l}\text { reflects the operating capacity and capital utilization } \\
\text { efficiency of the enterprise }\end{array}$ \\
\hline & basic earnings per share & $Y_{4}$ & reflects the market performance of enterprise value \\
\hline
\end{tabular}

When measuring efficiency, parametric stochastic frontier analysis (SFA) and data envelopment analysis (DEA) are two commonly used methods. In the actual calculation process, SFA requires that the output variable is single, which is often inconsistent with the actual situation. Therefore, DEA is often the best choice for measuring efficiency when the output variable is not unique [25]. DEA is a nonparametric technical efficiency analysis method based on relative comparisons among evaluated objects. It was proposed by American scholars Charnes, Cooper and Rhodes in 1978. The first model of DEA is called the CCR model, which is named after Charnes, Cooper and Rhodes [29]. In 1984, Banker, Charnes and Cooper added the convexity constraint (Equation (1)) to the CCR model to further distinguish pure technical efficiency from scale efficiency [30]. This model is called the BCC model. The specific model is set as follows: 


$$
\sum_{j=1}^{n} \lambda_{j}=1(\lambda \geq 0)
$$

Supposing the weight vector of the input factor is:

$$
\begin{gathered}
v=\left(v_{1}, v_{2}, v_{3}, \ldots, v_{\mathrm{m}}\right)^{T} \\
u=\left(u_{1}, u_{2}, u_{3}, \ldots, u_{\mathrm{s}}\right)^{T} \\
\sum_{\mathrm{i}=1}^{\mathrm{m}} v_{\mathrm{i}} x_{\mathrm{ij}}
\end{gathered}
$$

Then the output composite value is:

$$
\sum_{\mathrm{r}=1}^{\mathrm{s}} u_{\mathrm{r}} y_{\mathrm{rj}}
$$

The efficiency evaluation index of each decision unit is the ratio of the two integrated values:

$$
h_{\mathrm{j}}=\frac{\sum_{\mathrm{r}=1}^{\mathrm{s}} u_{\mathrm{r}} y_{\mathrm{rj}}}{\sum_{\mathrm{i}=1}^{\mathrm{m}} v_{\mathrm{i}} x_{\mathrm{ij}}}
$$

When $h_{\mathrm{j}}=1$, it means that the relative efficiency value of the decision unit reaches the maximum. Additionally, when $h_{\mathrm{j}}<1$, it means that the efficiency value of the decision unit still has some room for improvement.

For each decision unit, the dyadic model of the BCC model is shown as follows, and the corresponding efficiency values can be obtained through solutions.

$$
\begin{gathered}
\min \left[\theta-\varepsilon\left(\sum_{\mathrm{i}=1}^{\mathrm{m}} \mathrm{s}_{\mathrm{i}}^{-}+\sum_{\mathrm{r}=1}^{\mathrm{s}} \mathrm{s}_{\mathrm{r}}^{+}\right)\right. \\
\sum_{\mathrm{j}=1}^{\mathrm{n}} x_{\mathrm{ij}} \lambda_{\mathrm{j}}+\mathrm{s}_{\mathrm{i}}^{-}=\theta x_{\mathrm{ij}_{0}}, \mathrm{i} \in(1,2, \ldots, \mathrm{m}) \\
\sum_{\mathrm{j}=1}^{\mathrm{n}} y_{\mathrm{rj}} \lambda_{\mathrm{j}}-\mathrm{s}_{\mathrm{r}}^{+}=y_{\mathrm{rj}_{0}}, \mathrm{r} \in(1,2, \ldots, \mathrm{s}) \\
\quad \sum_{\mathrm{j}=1}^{\mathrm{n}} \lambda_{\mathrm{j}}=1 \\
\theta, \lambda_{\mathrm{j}}, \mathrm{s}_{\mathrm{i}}^{-}, \mathrm{s}_{\mathrm{r}}^{+} \geq 0, \mathrm{j} \in(1,2, \ldots, \mathrm{n})
\end{gathered}
$$

where $\mathrm{s}_{\mathrm{i}}^{-}$is the slack variable, $\mathrm{s}_{\mathrm{r}}^{+}$is the residual variable, $x_{\mathrm{ij}_{0}}$ represents the $\mathrm{i}$-th input of the $\mathrm{j}_{0}$-th decision unit, $y_{\mathrm{rj}_{0}}$ represents the $\mathrm{r}$-th output of the $\mathrm{j}_{0}$-th decision unit, $\varepsilon$ represents the Archimedean infinitesimal, which is usually taken as a positive infinitesimal, $\lambda_{j}$ represents the weight of the -th decision unit and $\theta$ represents its relative effective efficiency value.

When $\theta=1, \mathrm{~s}^{-}=0$ and $\mathrm{s}^{+}=0$, the corresponding decision unit is considered as DEA effective and satisfies being both technically effective and scale effective. When $\theta=1$, at least one of $\mathrm{s}^{-}$and $\mathrm{s}^{+}$is greater than 0 , the decision unit is weakly DEA effective and the conditions of being technically effective and scale effective are not satisfied at the same time. When $\theta<1, \mathrm{~s}^{-} \neq 0$ and $\mathrm{s}^{+} \neq 0$, the decision unit fails to achieve being DEA effective, and there is input redundancy or output deficiency.

To make up for the deficiency that the DEA model is only used for static evaluation, this paper used the total factor productivity (TFP) index method to conduct an effective dynamic comparison and analysis of decision units at different times [31,32]. The specific model is set up as follows: 


$$
M_{0}\left(x_{\mathrm{t}+1}, y_{\mathrm{t}+1}, x_{\mathrm{t}}, y_{\mathrm{t}}\right)=\frac{D_{0}^{\mathrm{t}+1}\left(x_{\mathrm{t}+1}, y_{\mathrm{t}+1}\right)}{D_{0}^{\mathrm{t}}\left(x_{\mathrm{t}}, y_{\mathrm{t}}\right)} \times \mathrm{s} \sqrt{\frac{D_{0}^{\mathrm{t}}\left(x_{\mathrm{t}+1}, y_{\mathrm{t}+1}\right)}{D_{0}^{\mathrm{t}+1}\left(x_{\mathrm{t}+1}, y_{\mathrm{t}+1}\right)} \times \frac{D_{0}^{\mathrm{t}}\left(x_{\mathrm{t}}, y_{\mathrm{t}}\right)}{D_{0}^{\mathrm{t}+1}\left(x_{\mathrm{t}}, y_{\mathrm{t}}\right)}}
$$

where $\frac{D_{0}^{\mathrm{t}+1}\left(x_{\mathrm{t}+1}, y_{\mathrm{t}+1}\right)}{D_{0}^{\mathrm{t}}\left(x_{\mathrm{t}}, y_{\mathrm{t}}\right)}$ represents the efficiency change (EC), and $\sqrt{\frac{D_{0}^{t}\left(x_{\mathrm{t}+1}, y_{\mathrm{t}+1}\right)}{D_{0}^{\mathrm{t}+1}\left(x_{\mathrm{t}+1}, y_{\mathrm{t}+1}\right)} \times \frac{D_{0}^{\mathrm{t}}\left(x_{\mathrm{t}}, y_{\mathrm{t}}\right)}{D_{0}^{\mathrm{t}+1}\left(x_{\mathrm{t}}, y_{\mathrm{t}}\right)}}$ represents the technical change (TC). Technical efficiency measures the level of technology in the production unit, and technical change refers to the impact of the firm's use of new levels of knowledge, skills and management on its economic activity.

The meaning of efficiency measured by the Malmquist index (MI) is as follows: When $M I>1$, it means that the productivity level of this DMU has increased. When $M I=1$, it means that the productivity level of this DMU has remained the same. When $M I<1$, it means that the productivity level of this DMU has decreased.

In the DEA model, input indicators and output indicators are required to be nonnegative. In the sample data, the financing cost ratio, return on net assets and basic earnings per share all contain negative values, meaning the original data need to be functionalized. All the index data $x_{\mathrm{ij}}$ were grouped into a positive value interval so that all the sample data are between 0 and 1 . To avoid the minimum value being normalized to zero, this study processed the original data as follows:

$$
y_{\mathrm{ij}}=\frac{x_{\mathrm{ij}}-m_{\mathrm{j}}}{M_{\mathrm{j}}-m_{\mathrm{j}}} \times 0.9+0.1
$$

where $i=1,2,3, \ldots, 7$ denotes the number of indicators, $j=1,2,3, \ldots, 70$ denotes the number of decision units, $\mathrm{m}_{\mathrm{j}}$ denotes $\min \left(x_{\mathrm{ij}}\right)$ and $M_{\mathrm{j}}$ denotes $\max \left(x_{\mathrm{ij}}\right)$.

\section{Driving Factors for Hydrogen Energy Financing Efficiency Evaluation}

Combining the main characteristics of hydrogen energy listed enterprises and the existing literature, this paper selected indicators from the external environment and internal factors of enterprises to explore the drivers of the financing efficiency of 70 hydrogen energy listed enterprises $[18,33]$. The comprehensive technical efficiency $(f e)$ of hydrogen energy was measured by the DEA model, and it was taken as a dependent variable. The GDP per capita of the province where the enterprise is located $(g d p p c)$ and systemic risk ( $s r)$ were used as external environment variables. The total assets $(t a)$, nature of the enterprise $(n f)$, equity-to-debt ratio ( $c r$ ), shareholding ratio of the first largest shareholder (sr1), cost-toincome ratio (cir), asset turnover ratio (ato) and return on total assets (rota) were taken as internal factor variables. Among them, the nature of the enterprise $(n f)$ is a dummy variable introduced to indicate the nature of listed enterprises. If it is 1 , it indicates state-owned enterprises; if it is 0 , it indicates non-state-owned enterprises. Table 2 shows the selection results of influencing indicators.

\begin{tabular}{|c|c|c|c|}
\hline Indicator Type & Indicator Name & Variable & Variable Description \\
\hline Dependent variable & Financing efficiency & fe & The capital scale of the enterprise \\
\hline \multirow{2}{*}{$\begin{array}{l}\text { Independent variable } \\
\text { (external factors) }\end{array}$} & Per capita GDP & $g d p p c$ & $\begin{array}{l}\text { The regional economic situation where the } \\
\text { enterprise is located }\end{array}$ \\
\hline & Systemic risk & $s r$ & $\begin{array}{l}\text { Market risks that are not expected and controlled } \\
\text { by the enterprise }\end{array}$ \\
\hline \multirow{7}{*}{$\begin{array}{l}\text { Independent variable } \\
\text { (internal factors) }\end{array}$} & Total assets & $t a$ & The size of the enterprise \\
\hline & Nature of the enterprise & $n f$ & $\begin{array}{c}\text { Dummy variable, } 1 \text { for existing enterprises and } 0 \\
\text { for non-state-owned enterprises }\end{array}$ \\
\hline & \multirow{5}{*}{$\begin{array}{l}\text { Equity-liability ratio } \\
\text { Shareholding ratio of the } \\
\text { largest shareholder } \\
\text { Cost-income ratio } \\
\text { Asset turnover } \\
\text { Return on total assets }\end{array}$} & $\mathrm{cr}$ & The financing structure of the enterprise \\
\hline & & sr1 & The ownership concentration of the enterprise \\
\hline & & cir & The enterprise's cost input \\
\hline & & ato & The capital utilization efficiency of the enterprise \\
\hline & & rota & Market performance reflecting enterprise value \\
\hline
\end{tabular}

Table 2. Selection results of influencing indicators. 
The financing efficiency values measured using the DEA model are distributed between 0 and 1 , meaning the value range of explanatory variables in the model is restricted. In this case, regression using ordinary least squares (OLS) would lead to biased estimated parameters [34]. In contrast, tobit regression models are more suitable for situations where the dependent variable is restricted than traditional regression methods. Although the dependent variable is roughly continuously distributed in positive values in a tobit regression model, a portion of the observations have a positive probability of taking a value of zero [35]. Combining the characteristics of the financing efficiency of the explanatory variables in this paper and the hypotheses presented, the specific model is set as follows:

$f e_{\mathrm{it}}=\beta_{0}+\beta_{1} g d p p c_{\mathrm{it}}+\beta_{2} s r_{\mathrm{it}}+\beta_{3} t a_{\mathrm{it}}+\beta_{4} n f_{\mathrm{it}}+\beta_{5} c r_{\mathrm{it}}+\beta_{6} s r_{\mathrm{it}}+\beta_{7} c i r_{\mathrm{it}}+\beta_{8} a t o_{\mathrm{it}}+\beta_{9} r o t a_{\mathrm{it}}$

where $\mathrm{i}$ denotes the $\mathrm{i}$-th hydrogen energy listed enterprise, $\mathrm{t}$ denotes the year, $\beta_{0}$ is a constant term, $\beta_{1}, \beta_{2}, \ldots, \beta_{9}$ are coefficients to be estimated and the perturbation term is $\varepsilon_{\mathrm{it}} \sim \mathrm{N}\left(0, \sigma_{\varepsilon}^{2}\right)$.

\section{Empirical Results and Analysis}

\subsection{Basic Data}

A total of 8120 basic data were used in this paper; they came from a wind database, annual reports of enterprises, the National Bureau of Statistics and local bureaus of statistics (see Supplementary Tables S1-S18 for details).

\subsection{Measurement of Financing Efficiency}

Based on the DEA model, DEAP2.1 software was used to calculate the financing efficiency of 70 hydrogen energy listed enterprises in China from 2014 to 2020, which are shown in Supplementary Table S19.

\subsection{Financing Benefit Analysis of Hydrogen Energy Enterprises in Different Segments}

Overall, by comparing the financing efficiency of 70 hydrogen energy listed enterprises in China from 2014 to 2020, it can be observed that the maximum annual average financing efficiency was 0.99 , and the minimum was 0.42 . Then, this paper analyzed the financing efficiency of hydrogen energy from different segments (according to the segment classification standard in the wind database). As shown in Figure 1, the financing efficiencies of China's hydrogen energy in different segments have shown upward trends, the hydrogen energy financing efficiency of the fuel cell sector has been significantly higher than that of other segments and the gap has gradually narrowed in recent years. Up to 2020, it has already caught up to 0.90 . Meanwhile, the financing efficiency has improved rapidly in the enterprises that develop two business segments at the same time. The main reason is that hydrogen energy has been regarded as a vital method to promote the achievement of China's carbon peak and carbon neutrality goals. For example, hydrogen energy was written into the "Government Work Report" in 2019. Under this background, various types of capital have also poured into the field of hydrogen energy. Finally, they provide a good policy environment and financial support for hydrogen energy industry development. It is foreseen that more enterprises will carry out hydrogen energy business in the future, and the effective improvement in financing efficiency will become the key to realizing the long-term development of enterprises. 


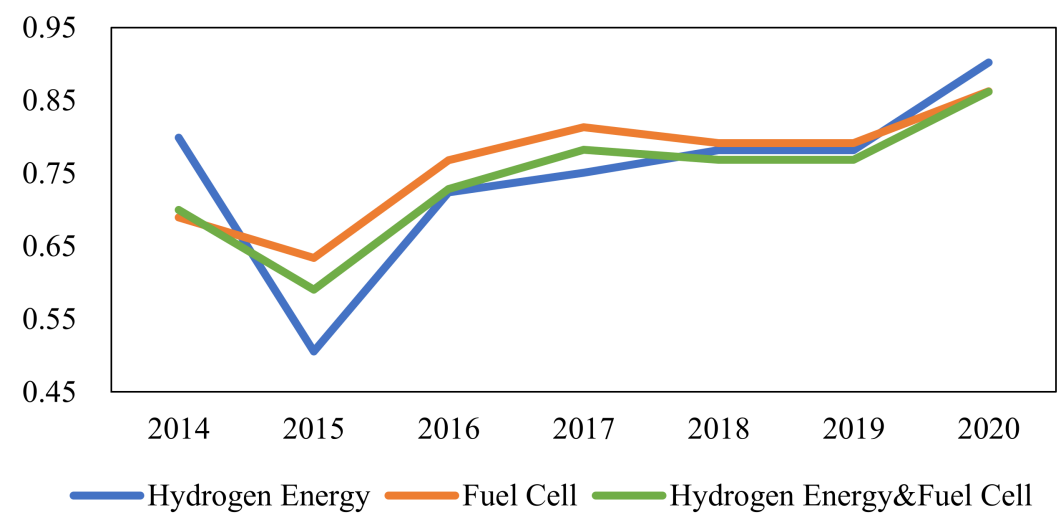

Figure 1. Financing efficiency value by concept.

\subsection{Financing Benefit Analysis of Hydrogen Energy Enterprises in Different Areas}

Considering that there is a certain regional agglomeration of hydrogen energy enterprises in China, and that their development may be influenced by the regional economic development, this paper further divided the enterprises according to different areas. It was found that the enterprises with higher financing efficiency are mostly located in the eastern coastal areas. According to the classification results, the number of enterprises in the eastern, central and western areas is 47,13 and 10, respectively, including 15 in Jiangsu Province, 6 in Shandong Province, 6 in Guangdong Province and 6 in Zhejiang Province. They are all located in the eastern coastal areas, with strong local aggregation characteristics. As shown in Figure 2, it can be observed that the financing efficiency was higher in the eastern and central areas and lower in the western areas, which is in line with the economic development. Areas with relatively developed economic development are relatively more strongly supported by the government. The quantity and quality of investors in these areas are also relatively better. Therefore, enterprises in these areas face a better financing environment. According to the economic development and the agglomeration characteristics of enterprise development, China has also introduced a policy support program to reward the hydrogen energy demonstration city clusters by means of "awards and subsidies". Recently, the " $1+6$ " demonstration urban agglomeration was formed by six cities (areas), including Shanghai, Suzhou, Nantong, Jiaxing, Zibo, Ningdong and Ordos. Additionally, the Beijing-Tianjin-Hebei hydrogen fuel cell vehicle demonstration city cluster, led by Beijing, has been officially approved. It can be expected that it will create better conditions to improve the financing efficiency of enterprises in these demonstration urban agglomerations. Meanwhile, in a broader discussion, the better financing efficiency in the eastern coastal areas can be an advance of China in accelerating the shift towards a hydrogen economy in the Association of Southeast Asian Nations (ASEAN). For example, from the current development status of hydrogen energy industries in various countries, different utilization routes can be explored, including the application of green hydrogen in the transportation, power generation, industry and utility sectors together with Malaysia, the Philippines, Thailand and other emerging economies. Additionally, it can promote strengthening the ability of internal agglomeration and external radiation and further promote the development of ASEAN integration [36-38]. 


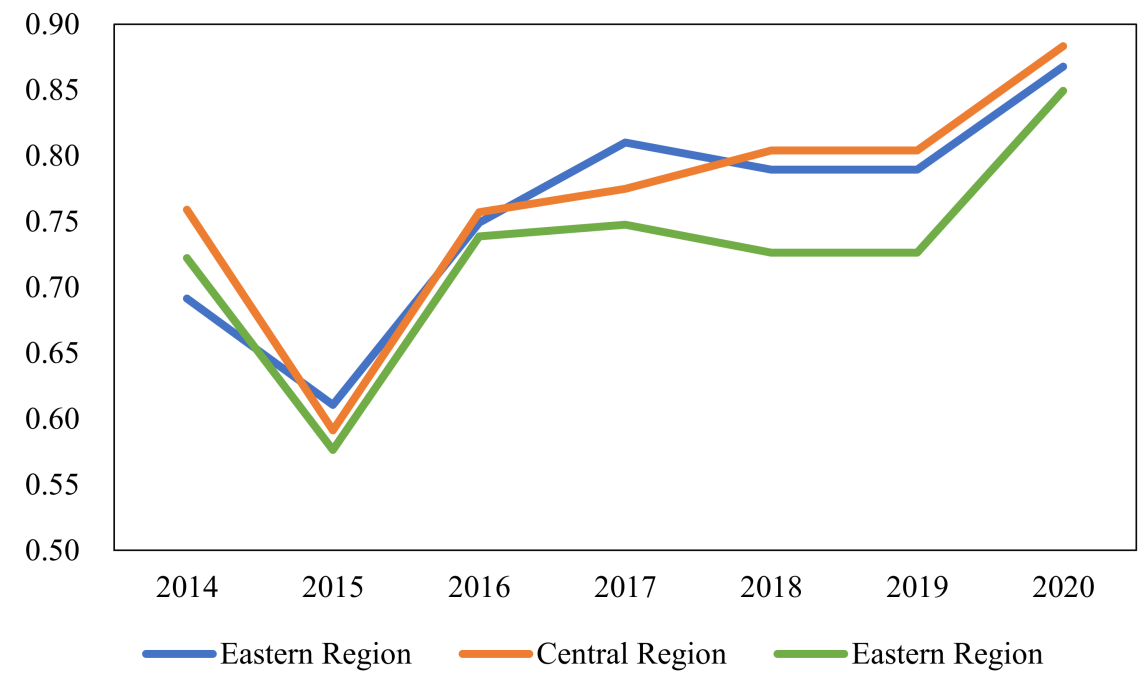

Figure 2. Financing efficiency value by areas.

As shown in Table 3, the overall average Malmquist index is 1.014, which indicates that the overall financing efficiency of hydrogen energy listed enterprises has shown an upward trend throughout the whole sample observation period. The Malmquist index can be decomposed into the technical efficiency change index and the technical progress index. As shown in Table 3, the overall technical efficiency change increased by $3.4 \%$ from 2014 to 2020 , while the technical progress decreased by $2.0 \%$. Therefore, the decrease in corporate financing efficiency was mainly caused by the decrease in technical progress efficiency. This indicates that the overall hydrogen energy listed enterprises lack the ability to apply new knowledge and skills and improve management during the sample period, resulting in the decrease in corporate financing efficiency. In addition, the technical efficiency change is further composed of two components: pure technical efficiency change and scale efficiency change. As shown in Table 3, the overall pure technical change decreased by $1.0 \%$, and scale efficiency increased by $4.4 \%$. Therefore, the rise in technical efficiency change was mainly due to the increase in firm size. However, it is not a long-term strategy for hydrogen energy enterprises to improve financing efficiency by enlarging the scale efficiency. To realize the long-term and healthy development of enterprises, it is essential to continuously realize technological breakthroughs. Therefore, hydrogen energy enterprises have a long way to go in terms of technological innovation.

Table 3. Malmquist index dynamic analysis results.

\begin{tabular}{cccccc}
\hline Years & EC & TP & PC & SC & TFP \\
\hline $2014-2015$ & 0.823 & 0.845 & 0.632 & 1.302 & 0.695 \\
$2015-2016$ & 1.266 & 0.809 & 1.248 & 1.014 & 1.024 \\
$2016-2017$ & 1.079 & 0.99 & 1.078 & 1.001 & 1.068 \\
$2017-2018$ & 0.977 & 1.162 & 0.988 & 0.989 & 1.134 \\
$2018-2019$ & 0.949 & 0.88 & 0.939 & 1.011 & 0.835 \\
$2019-2020$ & 1.177 & 1.284 & 1.198 & 0.983 & 1.511 \\
Mean & 1.034 & 0.98 & 0.99 & 1.044 & 1.014 \\
\hline
\end{tabular}

\subsection{Study on the Drivers of Financing Efficiency}

\subsubsection{Descriptive Statistics of Variables}

As shown in Table 4, the mean value of financing efficiency is 0.7555 . The minimum value is 0.2110 , and the maximum value is 1.0000 . The standard deviation is 0.1876 , and the extreme deviation is 1.0444 times the mean value. This indicates that there is little difference in efficiency between enterprises. Among all the explanatory variables, the value of asset scale indicators varies greatly, with a minimum value of 0.0211 billion and a maximum of 
919.0000 billion. The standard deviation is 86.3295 , and the extreme deviation is 39.5105 times the mean. This shows a large variation in asset size among firms. In addition, due to the different levels of economic development between areas, the GDP per capita of the provinces, where the enterprises are located, also differs greatly. The eastern areas are relatively more economically developed, with a maximum value of CNY 164.8900 thousand in Beijing. The western area is relatively lagging in development, with a minimum value of CNY 26.1700 thousand in Gansu Province.

Table 4. Variable descriptive statistics.

\begin{tabular}{ccccccc}
\hline Variable & Unit & Obs & Mean & Std. Dev. & Min & Max \\
\hline$f e$ & - & 490 & 0.7555 & 0.1876 & 0.2110 & 1.0000 \\
$g d p p c$ & thousand yuan & 490 & 80.4275 & 32.5291 & 26.1700 & 164.8900 \\
$s r$ & - & 490 & 1.1161 & 0.7844 & -3.0289 & 8.1409 \\
$t a$ & billion yuan & 490 & 23.2591 & 86.3295 & 0.0211 & 919.0000 \\
$n f$ & - & 490 & 0.4000 & 0.4904 & 0.0000 & 1.0000 \\
$c r$ & - & 490 & 1.5767 & 1.6723 & 0.0042 & 13.8281 \\
sr1 & $\%$ & 490 & 32.5689 & 17.1339 & 0.0000 & 89.9900 \\
cir & $\%$ & 490 & 0.7477 & 0.1260 & 0.2873 & 1.1192 \\
ato & times & 490 & 0.6431 & 0.4137 & 0.0523 & 3.5623 \\
rota & $\%$ & 490 & 0.0368 & 0.0528 & -0.2416 & 0.2544 \\
\hline
\end{tabular}

\subsubsection{Correlation Coefficient Test}

To test the correlations of the selected explanatory variables and financing efficiency, the correlation coefficients were examined by the correlation coefficient method. As shown in Table 5, the correlation coefficients between GDP per capita, total assets, enterprise nature, equity-to-debt ratio, cost-to-income ratio, asset turnover ratio and return on total assets and financing efficiency are all significant at the $1 \%$ level. This indicates that these variables have good explanatory power on financing efficiency. Further, the correlation coefficients between total assets, enterprise nature and cost-to-income ratio and financing efficiency are significantly negative at the $1 \%$ level. This shows that these three indicators have a negative impact on financing efficiency. The reasons are further analyzed in the subsequent regression results.

Table 5. Correlation analysis between variables.

\begin{tabular}{|c|c|c|c|c|c|c|c|c|c|c|}
\hline Items & fe & $g d p p c$ & $s r$ & $t a$ & $n f$ & $c r$ & $s r 1$ & cir & ato & rota \\
\hline fe & 1 & & & & & & & & & \\
\hline$g d p p c$ & $\begin{array}{c}0.1394^{* * *} \\
(0.0020)\end{array}$ & 1 & & & & & & & & \\
\hline$s r$ & $\begin{array}{c}0.0744 \\
(0.1000)\end{array}$ & $\begin{array}{l}0.0837 * \\
(0.0642)\end{array}$ & 1 & & & & & & & \\
\hline$t a$ & $\begin{array}{c}-0.1674^{* * *} \\
(0.0002)\end{array}$ & $\begin{array}{c}0.1609^{* * *} \\
(0.0003)\end{array}$ & $\begin{array}{l}-0.0209 \\
(0.6439)\end{array}$ & 1 & & & & & & \\
\hline$n f$ & $\begin{array}{c}-0.1369^{* * * *} \\
(0.0024)\end{array}$ & $\begin{array}{c}-0.0916^{* *} \\
(0.0426)\end{array}$ & $\begin{array}{l}0.1202 * * \\
(0.0077)\end{array}$ & $\begin{array}{l}0.216^{* * *} \\
(0.0000)\end{array}$ & 1 & & & & & \\
\hline $\mathrm{cr}$ & $\begin{array}{c}0.3354^{* * * *} \\
(0.0000)\end{array}$ & $\begin{array}{l}-0.0507 \\
(0.2630)\end{array}$ & $\begin{array}{c}0.0197 \\
(0.6641)\end{array}$ & $\begin{array}{c}-0.1427^{* *} \\
(0.0015)\end{array}$ & $\begin{array}{c}-0.2705^{* * *} \\
(0.0000)\end{array}$ & 1 & & & & \\
\hline$s r 1$ & $\begin{array}{c}0.0622 \\
(0.1690)\end{array}$ & $\begin{array}{c}-0.0911^{* *} \\
(0.0438)\end{array}$ & $\begin{array}{l}-0.0467 \\
(0.3019)\end{array}$ & $\begin{array}{c}0.2616^{* * * *} \\
(0.0000)\end{array}$ & $\begin{array}{l}0.1031^{* *} \\
(0.0225)\end{array}$ & $\begin{array}{l}0.0763 * \\
(0.0915)\end{array}$ & 1 & & & \\
\hline cir & $\begin{array}{c}-0.2296^{* * * *} \\
(0.0000)\end{array}$ & $\begin{array}{c}0.02 \\
(0.6593)\end{array}$ & $\begin{array}{l}0.1074^{* *} \\
(0.0174)\end{array}$ & $\begin{array}{c}0.1635^{* * *} \\
(0.0003)\end{array}$ & $\begin{array}{c}0.4239 * * * \\
(0.0000)\end{array}$ & $\begin{array}{c}-0.4601 * * * * \\
(0.0000)\end{array}$ & $\begin{array}{c}0.044 \\
(0.3311)\end{array}$ & 1 & & \\
\hline ato & $\begin{array}{c}0.1272 * * * \\
(0.0048)\end{array}$ & $\begin{array}{c}-0.0747^{*} \\
(0.0984)\end{array}$ & $\begin{array}{l}-0.052 \\
(0.2506)\end{array}$ & $\begin{array}{c}0.1674^{* * * *} \\
(0.0002)\end{array}$ & $\begin{array}{c}0.1313 * * * * \\
(0.0036)\end{array}$ & $\begin{array}{c}-0.1918^{* * * *} \\
(0.0000)\end{array}$ & $\begin{array}{c}0.1303^{* * * *} \\
(0.0039)\end{array}$ & $\begin{array}{c}0.3453^{* * *} \\
(0.0000)\end{array}$ & 1 & \\
\hline rota & $\begin{array}{c}0.3562 * * * \\
(0.0000)\end{array}$ & $\begin{array}{l}-0.0045 \\
(0.9212)\end{array}$ & $\begin{array}{c}-0.1505^{\text {*** }} \\
(0.0008)\end{array}$ & $\begin{array}{c}0.0417 \\
(0.3569)\end{array}$ & $\begin{array}{c}-0.171^{* * * *} \\
(0.0001)\end{array}$ & $\begin{array}{c}0.2613 * * * \\
(0.0000)\end{array}$ & $\begin{array}{c}0.1309 * * * \\
(0.0037)\end{array}$ & $\begin{array}{c}-0.4639 * * * * \\
(0.0000)\end{array}$ & $\begin{array}{c}0.2128 * * * \\
(0.0000)\end{array}$ & 1 \\
\hline
\end{tabular}

Note: ${ }^{* * *},{ }^{* *}$ and ${ }^{*}$ indicate significance at the $1 \%, 5 \%$ and $10 \%$ levels, respectively.

\subsubsection{Multicollinearity Test}

To avoid the problem of multicollinearity among variables, this paper applied the variance inflation factor method to test multicollinearity for each explanatory variable. 
According to the test results in Table 6, it can be seen that the explanatory variable costto-income ratio (cir) has the largest VIF value of 2.17, and the mean value of VIF of the nine dependent variables is 1.38 , which is much smaller than 10 . Therefore, it is considered that there is no multicollinearity problem among the independent variables selected in this paper, and regression can be conducted.

Table 6. Multicollinearity test.

\begin{tabular}{ccc}
\hline Variable & VIF & $\mathbf{1 / V I F}$ \\
\hline cir & 2.17 & 0.459939 \\
rota & 1.66 & 0.602102 \\
ato & 1.46 & 0.68292 \\
$c r$ & 1.34 & 0.747674 \\
$n f$ & 1.32 & 0.7604 \\
$t a$ & 1.21 & 0.829644 \\
$s r 1$ & 1.14 & 0.878155 \\
$g d p p c$ & 1.09 & 0.91453 \\
$s r$ & 1.06 & 0.94578 \\
\hline
\end{tabular}

\subsubsection{Cointegration Test}

To avoid pseudo-regression, this paper used the Kao test to test stable equilibrium relationships among the variables [39]. The results are shown in Table 7. It can be seen that the $p$-values of the statistics MDF, DF and ADF are all less than 0.05. Therefore, the original hypothesis is rejected, indicating that there is a cointegration relationship among the variables, and that the original variables can be used for regression.

Table 7. Cointegration test.

\begin{tabular}{ccc}
\hline Item & Statistic & $p$-Value \\
\hline Modified Dickey-Fuller t (MDF) & -3.6655 & $0.0001^{* * *}$ \\
Dickey-Fuller t (DF) & -10.4394 & $0.0000^{* * *}$ \\
Augmented Dickey-Fuller t (ADF) & -1.9397 & $0.0262^{* *}$ \\
\hline
\end{tabular}

Note: ${ }^{* * *}$ and $^{* *}$ indicate significance at the $1 \%$ and $5 \%$ levels, respectively.

\subsubsection{Model Regression Results}

Based on the above variables, the regression model was constructed, and the preliminary regression results are shown in Model 1 of Table 8.

Table 8. Tobit model regression results.

\begin{tabular}{|c|c|c|c|c|}
\hline Item & Model 1 & Model 2 & Model 3 & Model 4 \\
\hline$g d p p c$ & $\begin{array}{c}0.0150 * * * \\
(0.000)\end{array}$ & $\begin{array}{c}0.0148^{* * *} \\
(0.000)\end{array}$ & $\begin{array}{c}0.0149^{* * *} \\
(0.000)\end{array}$ & $\begin{array}{c}0.0149^{* * *} \\
(0.000)\end{array}$ \\
\hline$s r$ & $\begin{array}{c}0.0235^{* *} \\
(0.012)\end{array}$ & $\begin{array}{c}0.0239^{* *} \\
(0.010)\end{array}$ & $\begin{array}{c}0.0234^{* *} \\
(0.011)\end{array}$ & $\begin{array}{c}0.0232^{* *} \\
(0.012)\end{array}$ \\
\hline$t a$ & $\begin{array}{c}-0.0000^{* * *} \\
(0.000)\end{array}$ & $\begin{array}{c}-0.0000^{* * * *} \\
(0.000)\end{array}$ & $\begin{array}{c}-0.0000^{* * *} \\
(0.000)\end{array}$ & $\begin{array}{c}-0.0000^{* * * *} \\
(0.000)\end{array}$ \\
\hline$n f$ & $\begin{array}{l}0.0082 \\
(0.684)\end{array}$ & 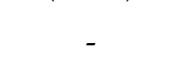 & 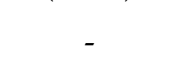 & 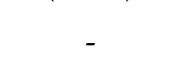 \\
\hline$c r$ & $\begin{array}{c}0.0292^{* * *} \\
(0.000)\end{array}$ & $\begin{array}{c}0.0290^{* * *} \\
(0.000)\end{array}$ & $\begin{array}{c}0.0299 * * * \\
(0.000)\end{array}$ & $\begin{array}{c}0.0306^{* * * *} \\
(0.000)\end{array}$ \\
\hline sr1 & $\begin{array}{l}0.0007 \\
(0.184)\end{array}$ & $\begin{array}{l}0.0007 \\
(0.177)\end{array}$ & $\begin{array}{l}0.0007 \\
(0.193)\end{array}$ & r \\
\hline cir & $\begin{array}{c}-0.0663 \\
(0.488)\end{array}$ & $\begin{array}{c}-0.0549 \\
(0.548)\end{array}$ & - & - \\
\hline ato & $\begin{array}{c}0.0889^{* * *} \\
(0.000)\end{array}$ & $\begin{array}{c}0.0884^{* * *} \\
(0.000)\end{array}$ & $\begin{array}{c}0.0823^{* * * *} \\
(0.000)\end{array}$ & $\begin{array}{c}0.0847^{* * * *} \\
(0.000)\end{array}$ \\
\hline
\end{tabular}


Table 8. Cont.

\begin{tabular}{ccccc}
\hline Item & Model 1 & Model 2 & Model 3 & Model 4 \\
\hline rota & $0.8209^{* * *}$ & $0.8252^{* * *}$ & $0.8849^{* * *}$ & $0.8931^{* * *}$ \\
& $(0.000)$ & $(0.000)$ & $(0.000)$ & $(0.000)$ \\
cons & $0.5198^{* * *}$ & $0.5065^{* * *}$ & $0.4662^{* * *}$ & $0.4853^{* * *}$ \\
Prob & $(0.000)$ & $(0.000)$ & $(0.000)$ & $(0.000)$ \\
Note: ${ }^{* * *}$ and ${ }^{* *}$ indicate significance at the $1 \%$ and 5\% levels, respectively. & 0.012 & 0.008 \\
\hline
\end{tabular}

According to the regression results of Model 1, the $p$-values of the variables GDP per capita in the province where the enterprise is located ( $g d p p c)$, systemic risk ( $s r)$, total assets $(t a)$, equity-to-debt ratio $(c r)$, asset turnover ratio $(a t o)$, return on total assets $($ rota $)$ and the constant term are all less than 0.01 . Therefore, these variables have a significant effect on financing efficiency at the $1 \%$ confidence level. Additionally, the $p$-values of the variables $n f, s r 1$ and cir are all greater than 0.1 , indicating that these three variables are not significant in the model. In this paper, the insignificant variables were removed and regressed again according to the 5\% confidence level. Finally, Model 4 was obtained. In Model 4, all variables are significant at the 5\% level, and the $p$-value of the Wald and LR tests is 0.008 , indicating that the model is significant from the overall perspective.

For external influencing factors, the GDP per capita of the province where the enterprise is located shows a positive correlation with financing efficiency, which is in line with the economic development. There are differences in the economic development levels of different areas. Provinces with better economic development have more participants in the capital market, more efficient allocation of resources and a better financing environment. They are more conducive to the improvement in the financing efficiency of hydrogen energy listed enterprises.

Systemic risk shows a positive relationship with the financing efficiency of hydrogen listed enterprises. By definition, $s r$ is a risk factor that measures the volatility of a stock relative to the overall market. The higher the $s r$, the more volatile the stock is, the greater the investment opportunity for investors and the higher the systemic risk faced. For hydrogen energy enterprises, high risk often means more capital inflows, especially in the early stage of development of the enterprise. Despite the high systemic risk, the enterprise often receives more financial support because of policy support and the trend of green economy development. With scientific management and efficient use of funds, the financing efficiency will be further enhanced. However, it should still be noted that high risk and high return will always go hand in hand. Therefore, keeping the risk within a reasonable range is always the best strategy for scientific development.

From the perspective of internal factors, total assets have a negative impact on financing efficiency. On the one hand, as the hydrogen energy industry is still in the initial development stage, and the larger enterprises are usually transformed from traditional energy enterprises, there may still be traditional lagging ideas in terms of financing. Thus, it fails to take advantage of the scale advantage. On the other hand, it can also be seen that enterprises cannot simply rely on expanding the scale to improve the comprehensive technical efficiency. They must have a practical development positioning and accurate analysis of the market. Additionally, at the same time, they need to have the core technology and products that allow enterprises to "stand on their own feet", in order to expand the scale of enterprises in a targeted manner and achieve long-term development.

There is a positive correlation between the equity-liability ratio and financing efficiency. In recent years, the government has encouraged the hydrogen energy industry to use market-based means for equity financing. Compared with the traditional debt financing, equity financing does not need to bear the interest of debt, which reduces the financial pressure of enterprises and eliminates the complicated procedures of bank borrowing, meaning that funds can be obtained more quickly. Therefore, enterprises prefer equity 
financing and make full use of the capital market, which is conducive to improving the efficiency of corporate financing.

There is a positive relationship between asset turnover and financing efficiency. The higher the asset turnover rate, the more efficient an enterprise is in managing and utilizing its assets. With the "dual carbon" goal, the development of clean energy has been raised to a new level. The market demand for hydrogen energy is increasing rapidly. Additionally, as a strategic emerging industry in China, hydrogen energy enterprises have conducted scientific management and made efficient use of capital under the guidance and support of the government, which not only proves the strong capital allocation ability of enterprises but also makes it easier for enterprises to obtain capital support in the process of financing, and to use capital to obtain income faster.

The return on total assets and financing efficiency shows a positive correlation. This means that enterprises with higher profitability are more likely to be favored by investors. Therefore, it is easier for them to obtain funds. Additionally, they can invest funds to obtain greater benefits, meaning they can obtain higher financing efficiency. This is in line with the operation rules of the capital market, where improving the profitability of an enterprise can effectively attract capital inflows, thus forming a virtuous circle.

In addition, the nature of the enterprise, the shareholding ratio of the largest shareholder and the cost-income ratio have no significant influence on financing efficiency. From the viewpoint of enterprise nature, state-owned enterprises and non-state-owned enterprises do not have a significant influence on financing efficiency, which indicates that, as the financing channels of hydrogen energy listed enterprises are broadened, state-owned and non-state-owned enterprises can compete at the same stage and develop in a balanced way, and the proportion of resource allocation is more determined by the market than government control. In terms of the shareholding ratio of the first largest shareholder, the concentration of equity does not affect financing efficiency. This indicates that the largest shareholder does not have a greater influence on enterprises' financing decision-making style in terms of business management. However, in the future development process of the hydrogen energy listed enterprises, the shareholding ratio of the first largest shareholder should also be controlled to avoid an excessive concentration of equity that may affect the financing efficiency of the enterprise. From the aspect of the cost-to-income ratio, the size of corporate input cost fails to have an impact on financing efficiency. This paper suggests that this is due to the characteristics of the hydrogen energy industry. The cost investment for technology R\&D generally has the characteristics of a large amount of funds and a long payback period, meaning the amount of cost investment may require a longer period of development to have an impact on financing efficiency.

\section{Conclusions and Policy Recommendation}

According to the results of the DEA model and the Malmquist index, the financing efficiency of 70 hydrogen energy listed enterprises in China, as a whole, is on the rise, mainly due to the improvement in scale efficiency. The financing efficiency of the fuel cell sector is significantly higher than that of the hydrogen energy sector. However, because of the carbon peak and carbon neutrality goals, hydrogen energy policy implementation and the influx of capital, the financing efficiency of the hydrogen energy sector has improved significantly. In addition, there is a certain regional agglomeration of hydrogen energy enterprises in China, the financing efficiency also shows a pattern that corresponds to the regional economic development and the enterprises with higher efficiency are mostly distributed in the eastern coastal areas.

According to the results of the tobit regression, it can be seen that the regional economic development level, systemic risk, enterprise size, financing structure, efficiency of utilization of funds and profitability have significant effects on the financing efficiency of hydrogen energy listed enterprises in China. Therefore, the following policy recommendations are proposed to improve the financing efficiency of hydrogen energy listed enterprises in China and to help achieve the "dual carbon" goal. 


\subsection{Improve the Hydrogen Energy Industry Policy and Optimize the Financial Support System}

On the one hand, policies related to the hydrogen energy industry should be improved. In recent years, the support for the hydrogen energy industry in China has been strengthened, and local hydrogen energy development plans and incentive policies have been successively promulgated by local governments. However, the policy standards of each area are fragmented and cannot coordinate with each other. Therefore, at this stage, China should speed up the research process of national hydrogen energy development planning, in order to provide guidance for the coordinated development of the hydrogen energy industry among different areas. Meanwhile, local policy formulation should be as clear, detailed and standardized as possible. It is important to enhance the operability in the process of concrete implementation to guarantee the realization of the policy targets. Take the subsidy policy of the hydrogen energy industry as an example; the relevant policy should be updated and improved with the continuous development of hydrogen energy technology. Additionally, the specific conditions of subsidies should be clarified to prevent policy subsidy abuse or even subsidy cheating.

On the other hand, the financial support system should be optimized. Different hydrogen energy listed enterprises have different demands for financial services in the capital market. Currently, problems still exist in China's capital market, such as difficulty of access and obvious administrative intervention, which affect the financing efficiency of hydrogen energy listed enterprises. Firstly, it is suggested to continuously optimize the primary market of China's stock, promote the construction of a multi-level capital market and satisfy the financing demands of different industries in a more targeted way. Secondly, reducing administrative intervention and playing the role of market can promote the enthusiasm of investors and financiers. Thirdly, the difficulty of hydrogen energy technology research and development has increased the risk of investment; thus, strengthening the support for "green credit policy" and broadening the financing channels of hydrogen energy listed enterprises are needed. Additionally, the development of debt capital will also improve the efficiency of capital allocation in the high-tech industry.

\subsection{Improve Technological Innovation and Accelerate the Training of Enterprise Talents}

Technological progress and technical efficiency are of great significance to enhance enterprise financing efficiency. In recent years, China's hydrogen energy technology has made great progress, but the core components rely on imports, which is not conducive to the development of China's hydrogen energy industry [40]. Therefore, continuous improvement in technological innovation should be paid more attention to promote the hydrogen energy industry's sustainable development. In addition, the innovation of technology is inseparable from the construction of enterprise-related talent teams. The hydrogen energy industry is in a period of rapid development and needs a large number of talents to apply new management knowledge and technical knowledge to promote the overall improvement in enterprises. Therefore, hydrogen energy enterprises should speed up the introduction of relevant talents and cultivate a high-quality team that meets the needs of enterprise development.

\subsection{Improve Financing Structure and Broaden Financing Channels}

The research results show that more enterprises favor equity financing. Equity financing has the advantages of a low capital threshold, a low financial risk, a low financing risk, etc., and can effectively help enterprises improve their management structure and system [41]. For hydrogen energy enterprises in the early stage of development, the result of equity financing is often a multiplier effect, which brings capital and partners who can help enterprises improve their strategic capabilities. In the past, in the hydrogen energy industry, enterprises used more debt financing methods to promote development, such as bank loans and policy-based loans. However, the interest rates generated by such financing have placed financial pressure on enterprises. Therefore, it is suggested that hydrogen energy enterprises should appropriately adjust their financing structure, broaden more 
financing channels, absorb more different types of capital and invest in the operation process, in order to improve the level of financing efficiency.

\subsection{Improving Management Level and Profitability}

Improving the profitability of enterprises can effectively attract the inflow of capital, and improving the management ability of the inflow and outflow of capital can further improve the profitability of enterprises, thus forming a virtuous circle. For hydrogen energy enterprises, improving their management level and enhancing their profitability are the top priorities at this stage of development. Enterprises should learn the experience and lessons from the historical development of new energy enterprises and should pay attention to the matching between the enterprise scale and the current situation of enterprise development. Meanwhile, enterprises make reasonable use of funds and formulate reasonable strategic plans for long-term development to realize the optimal allocation of funds.

From an overall perspective, the improvement in the financing efficiency of hydrogen energy listed enterprises is not the result of the external environment or internal factors alone, but a complex process of both synergistically to form a good financing environment and optimize the allocation of resources. Enterprises should give full play to their own initiative, always pay attention to the latest trends of hydrogen energy policies, explore the development rules of the hydrogen energy industry and make timely adjustments to their business decisions according to their own development status to adapt to the changes in the market. When the external environment and internal factors form a good interaction, it is advantageous to improve the financing efficiency of hydrogen energy listed enterprises from capital acquisition and utilization and become a strong support for hydrogen energy industry development.

\subsection{Limitations of this Study}

There are still many limitations in this study. Firstly, in terms of data, due to the late start of domestic hydrogen energy development and fewer enterprises being involved in hydrogen energy business, the sample scale available in this paper is small. Secondly, in terms of research methods and index selection, this paper used the DEA model to calculate only the relative efficiency between different DMUs, not the absolute efficiency. In addition, the selection of input and output items has a decisive impact on the efficiency evaluation results, and the selection of input and output items has a certain subjectivity, meaning it may affect the final results. When applying the tobit model for regression, this study did not take into account the fact that financing efficiency also depends on the availability of natural gas infrastructure, an advanced level of technology, the availability of the qualified workforce, etc. [42]. Thirdly, due to the limitation of the sample scale, this paper did not establish a further division according to the industrial chain, and the depth of analysis needs to be improved. In the future, with the continuous development and growth of the domestic hydrogen energy industry, relevant research will be more abundant. This study will continue to track domestic hydrogen energy enterprises' development, expand the sample scale in future research, use a variety of research methods for comparative research and systematically and comprehensively evaluate the financing efficiency of hydrogen energy enterprises, in order to further promote the healthy development of domestic hydrogen energy enterprises.

Supplementary Materials: The following are available online at https:/ / www.mdpi.com/article/10 .3390/en15010281/s1, Table S1: Basic Data of 70 Hydrogen Energy Listed Enterprises in China from 2014 to 2020, Table S2: Total Assets $\left(X_{1}\right)$ of 70 Hydrogen Energy Listed Enterprises in China from 2014 to 2020, Table S3: Asset Liability Ratio $\left(X_{2}\right)$ of 70 Hydrogen Energy Listed Enterprises in China from 2014 to 2020, Table S4: Financing Cost Rate $\left(X_{3}\right)$ of 70 Hydrogen Energy Listed Enterprises in China from 2014 to 2020, Table S5: Return on Equity $\left(\mathrm{Y}_{1}\right)$ of 70 Hydrogen Energy Listed Enterprises in China from 2014 to 2020, Table S6: Operating Income Growth Rate ( $\left.\mathrm{Y}_{2}\right)$ of 70 Hydrogen Energy Listed Enterprises in China from 2014 to 2020, Table S7: Total Assets Turnover $\left(\mathrm{Y}_{3}\right)$ of 70 Hydrogen Energy Listed Enterprises in China from 2014 to 2020, Table S8: Basic Earnings per Share $\left(\mathrm{Y}_{4}\right)$ of 70 
Hydrogen Energy Listed Enterprises in China from 2014 to 2020, Table S9: Financing Efficiency ( $f e$ ) of 70 Hydrogen Energy Listed Enterprises in China from 2014 to 2020, Table S10: Per Capita GDP $(g d p p c)$ of 70 Hydrogen Energy Listed Enterprises in China from 2014 to 2020, Table S11: Systemic Risk (sr) of 70 Hydrogen Energy Listed Enterprises in China from 2014 to 2020, Table S12: Total Assets $(t a)$ of 70 Hydrogen Energy Listed Enterprises in China from 2014 to 2020, Table S13: Nature of Enterprise $(n f)$ of 70 Hydrogen Energy Listed Enterprises in China from 2014 to 2020, Table S14: Equity Liability Ratio (cr) of 70 Hydrogen Energy Listed Enterprises in China from 2014 to 2020, Table S15: Shareholding Ratio of the Largest Shareholder ( $s r 1)$ of 70 Hydrogen Energy Listed Enterprises in China from 2014 to 2020, Table S16: Cost Income Ratio (cir) of 70 Hydrogen Energy Listed Enterprises in China from 2014 to 2020, Table S17: Asset Turnover (ato) of 70 Hydrogen Energy Listed Enterprises in China from 2014 to 2020, Table S18: Return on Total Assets (rota) of 70 Hydrogen Energy Listed Enterprises in China from 2014 to 2020, Table S19: Financing Efficiency of 70 Hydrogen Energy Listed Enterprises in China.

Author Contributions: Conceptualization, Y.C. and Y.P.; methodology, Y.C., Y.P., M.X. and M.Y.; validation, M.X.; formal analysis, Y.C., Y.P. and M.X.; writing-original draft preparation, M.X. and M.Y.; writing-review and editing, Y.P., M.X. and Y.Z. All authors have read and agreed to the published version of the manuscript.

Funding: This research was funded by the Beijing Postdoctoral Research Foundation, the State Grid Hebei Electric Power Co., Ltd. Project, "Research on New Power System Development Path", and the Ministry of Education Humanities and Social Sciences Research Program Fund (21YJA790009).

Institutional Review Board Statement: Not applicable.

Informed Consent Statement: Not applicable.

Data Availability Statement: Not applicable.

Acknowledgments: The authors gratefully appreciate the reviewers for their constructive comments and suggestions.

Conflicts of Interest: The authors declare no conflict of interest.

\section{References}

1. Rogelj, J.; Den Elzen, M.; Höhne, N.; Fransen, T.; Fekete, H.; Winkler, H.; Schaeffer, R.; Sha, F.; Riahi, K.; Meinshausen, M. Paris Agreement climate proposals need a boost to keep warming well below $2{ }^{\circ} \mathrm{C}$. Nature 2016, 534, 631-639. [CrossRef] [PubMed]

2. Huang, M.T.; Zhai, P.M. Achieving Paris Agreement temperature goals requires carbon neutrality by middle century with far-reaching transitions in the whole society. Adv. Clim. Chang. Res. 2021, 12, 281-286. [CrossRef]

3. Ajanovic, A.; Haas, R. Economic prospects and policy framework for hydrogen as fuel in the transport sector. Energy Policy 2018, 123, 280-288. [CrossRef]

4. Zhao, F.; Mu, Z.; Hao, H.; Liu, Z.; He, X.; Victor Przesmitzki, S.; Ahmad Amer, A. Hydrogen Fuel Cell Vehicle Development in China: An Industry Chain Perspective. Energy Technol. 2020, 8, 2000179. [CrossRef]

5. Meng, X.Y.; Gu, A.; Wu, X.G.; Zhou, L.L.; Zhou, J.; Liu, B.; Mao, Z.Q. Status quo of China hydrogen strategy in the field of transportation and international comparisons. Int. J. Hydrogen Energy 2021, 46, 28887-28899. [CrossRef]

6. Klimek, D.; Jedrych, E. A Model for the Sustainable Management of Enterprise Capital. Sustainability 2021, 13, 183. [CrossRef]

7. Modigliani, F.; Miller, M.H. The Cost of Capital Corporation Finance and the Theory of Investment. Am. Econ. Rev. 1959, 48, 443-453.

8. Modigliani, F.; Miller, M.H. Corporate Income Taxes and the Cost of Capital: A Correction. Am. Econ. Rev. 1963, 53, 433-443.

9. Romano, C.A.; Tanewski, G.A.; Smyrnios, K.X. Capital structure decision making: A model for family business. J. Bus. Ventur. 2001, 16, 285-310. [CrossRef]

10. Almeida, H.; Wolfenzon, D. The effect of external finance on the equilibrium allocation of capital. J. Financ. Econ. 2005, 75, 133-164. [CrossRef]

11. Brown, J.R.; Fazzari, S.M.; Petersen, B.C. Financing Innovation and Growth: Cash Flow, External Equity, and the 1990s R\&D Boom. J. Financ. 2010, 64, 151-185.

12. Xiao, J.; Ma, Y.J. Enterprise financing efficiency and theoretical analysis framework. Financ. Econ. 2004, S1, 337-340.

13. Tian, P.; Lin, B.Q. Impact of financing constraints on firm's environmental performance: Evidence from China with survey data. J. Clean. Prod. 2019, 217, 432-439. [CrossRef]

14. Guild, P.D.; Bachher, J.S. Equity investment decisions for technology based ventures. Int. J. Technol. Manag. 1996, 12, 787-795.

15. Lin, B.Q.; Bin, X. How to promote the growth of new energy industry at different stages? Energy Policy 2018, 118, 390-403. [CrossRef] 
16. Lyu, X.H.; Shi, A.N. Research on the Renewable Energy Industry Financing Efficiency Assessment and Mode Selection. Susainability 2018, 10, 222. [CrossRef]

17. Koengkan, M. Capital stock development and their effects on investment expansion in renewable energy in Latin America and the Caribbean region. J. Sustain. Financ. Investig. 2020, 1-18. [CrossRef]

18. Fuinhas, J.A.; Koengkan, M.; Santiago, R. The role of public, private, and public-private partnership capital stock on the expansion of renewable energy investment in Latin America and the Caribbean region. Phys. Cap. Dev. Energy Transit. Lat. Am. Caribb. 2021, 137-173. [CrossRef]

19. Zeng, M.; Liu, X.M.; Li, Y.L.; Peng, L.L. Review of renewable energy investment and financing in China: Status, mode, issues and countermeasures. Renew. Sustain. Energy Rev. 2014, 31, $23-37$.

20. Jin, Y.; Gao, X.; Wang, M. The financing efficiency of listed energy conservation and environmental protection firms: Evidence and implications for green finance in China. Energy Policy 2021, 153, 112254. [CrossRef]

21. Wiser, R.H.; Pickle, S.J. Financing investments in renewable energy: The impacts of policy design. Renew. Sustain. Energy Rev. 1998, 2, 361-386. [CrossRef]

22. Bai, R.; Lin, B.Q.; Liu, X.Y. Government subsidies and firm-level renewable energy investment: New evidence from partially linear functional-coefficient models. Energy Policy 2021, 159, 112610. [CrossRef]

23. Ari, I.; Koc, M. Philanthropic-crowdfunding-partnership: A proof-of-concept study for sustainable financing in low-carbon energy transitions. Energy 2021, 222, 119925. [CrossRef]

24. Caneparo, L. Financing the (Environmental) Quality of Cities with Energy Efficiency Investments. Sustainability 2020, $12,8809$. [CrossRef]

25. Koengkan, M.; Fuinhas, J.A.; Kazemzadeh, E.; Osmani, F.; Alavijeh, N.K.; Auza, A.; Teixeira, M. Measuring the economic efficiency performance in Latin American and Caribbean countries: An empirical evidence from stochastic production frontier and data envelopment analysis. Int. Econ. 2022, 169, 43-54. [CrossRef]

26. Vo, M.T. Capital structure and cost of capital when prices affect real investments. J. Econ. Bus. 2021, 113, 105944. [CrossRef]

27. Livdan, D.; Nezlobin, A. Investment, capital stock, and replacement cost of assets when economic depreciation is non-geometric. J. Financ. Econ. 2021, 142, 1444-1469. [CrossRef]

28. Simar, L.; Wilson, P.W. Estimation and inference in two-stage, semi-parametric models of production processes. J. Econom. 2007, 136, 31-64. [CrossRef]

29. Charnes, A.; Cooper, W.W.; Rhodes, E. Measuring the efficiency of decision making units. Eur. J. Oper. Res. 1978, 2, 429-444. [CrossRef]

30. Banker, R.D.; Charnes, A.; Cooper, W.W. Some models for estimating technical and scale inefficiencies in DEA. Manag. Sci. 1984, 32, 1613-1627. [CrossRef]

31. Fre, R.; Grosskopf, S.; Lindgren, B.; Roos, P. Productivity Changes in Swedish Pharamacies 1980-1989: A Non-Parametric Malmquist Approach; Springer: Dordrecht, The Netherlands, 1992.

32. Ray, S.; Desli, E. Productivity Growth, Technical Progress, and Efficiency Change in Industrialized Countries: Comment. Am. Econ. Rev. 1997, 87, 1033-1039.

33. Sun, C.; Zhan, Y.; Du, G. Can value-added tax incentives of new energy industry increase firm's profitability? Evidence from financial data of China's listed companies. Energy Econ. 2020, 86, 104654. [CrossRef]

34. Jebali, E.; Essid, H.; Khraief, N. The analysis of energy efficiency of the Mediterranean countries: A two-stage double bootstrap DEA approach. Energy 2017, 134, 991-1000. [CrossRef]

35. Tobin, J. Estimation of Relationships for Limited Dependent Variables. Econometrica 1958, 26, 24-36. [CrossRef]

36. Mah, A.X.Y.; Ho, W.S.; Bong, C.P.C.; Hassim, M.H.; Liew, P.Y.; Asli, U.A.; Kamaruddin, M.J.; Chemmangattuvalappil, N.G. Review of hydrogen economy in Malaysia and its way forward. Int. J. Hydrogen Energy 2019, 44, 5661-5675. [CrossRef]

37. Collera, A.A.; Agaton, C.B. Opportunities for production and utilization of green hydrogen in the Philippines. Int. J. Energy Econ. Policy 2021, 11, 37-41. [CrossRef]

38. Srisiriwat, A.; Pirom, W. Feasibility Study of Seawater Electrolysis for Photovoltaic/Fuel Cell Hybrid Power System for the Coastal Areas in Thailand. IOP Conf. Ser. Mater. Sci. Eng. 2017, 241, 12041. [CrossRef]

39. Kao, C. Spurious regression and residual-based tests for cointegration in panel data. J. Econom. 1999, 90, 1-44. [CrossRef]

40. Ren, J.; Andreasen, K.P.; Sovacool, B.K. Viability of hydrogen pathways that enhance energy security: A comparison of China and Denmark. Int. J. Hydrogen Energy 2014, 39, 15320-15329. [CrossRef]

41. Drover, W.; Busenitz, L.; Matusik, S.; Townsend, D.; Anglin, A.; Dushnitsky, G. A Review and Road Map of Entrepreneurial Equity Financing Research: Venture Capital, Corporate Venture Capital, Angel Investment, Crowdfunding, and Accelerators. J. Manag. 2017, 43, 1820-1853. [CrossRef]

42. Sadik-Zada, E.R. Political Economy of Green Hydrogen Rollout: A Global Perspective. Sustainability 2021, 13, 13464. [CrossRef] 